Drafting the Nepal Constitution, 1990

Author(s): Michael Hutt

Source: Asian Survey, Vol. 31, No. 11 (Nov., 1991), pp. 1020-1039

Published by: University of California Press

Stable URL: https://www.jstor.org/stable/2645305

Accessed: 21-06-2019 12:36 UTC

JSTOR is a not-for-profit service that helps scholars, researchers, and students discover, use, and build upon a wide range of content in a trusted digital archive. We use information technology and tools to increase productivity and facilitate new forms of scholarship. For more information about JSTOR, please contact support@jstor.org.

Your use of the JSTOR archive indicates your acceptance of the Terms \& Conditions of Use, available at https://about.jstor.org/terms 


\section{DRAFTING THE NEPAL CONSTITUTION, 1990}

\section{Michael Hutt}

On November 9, 1990, King Birendra Bir Bikram Shah promulgated a new constitution for the Kingdom of Nepal that enshrined several basic concepts which the country's banned political parties had demanded ever since King Mahendra's "royal coup" of December 15, 1960. The constitution has so far proved generally acceptable to the principal political parties in Nepal and is the main achievement of the Movement for the Restoration of Democracy launched on February 18, 1990. It is also the latest product of a long search for appropriate political institutions and processes in Nepal, begun soon after the British departure from India and the subsequent collapse of the Rana regime in 1950-51.

The 1990 Constitution is Nepal's fifth. The first one was promulgated in 1948 and was an attempt by the ruler of the time, Padma Shamsher, to shore up the fast-crumbling Rana regime. After it collapsed, an Interim Government Act came into force in 1951 and was not replaced until 1959, the year of Nepal's first general election. In 1960, King Mahendra revoked this "democratic" constitution, using the emergency powers it had granted him, and he reassumed all powers of government. Although amended three times, the 1962 Constitution promulgated for "a partyless Panchayat democracy," remained in force until 1990. It banned political parties, vested sovereignty in the king, and made him the source of all legislative, executive, and judicial power; the 1962 Constitution has, therefore, always been controversial, not to say notorious. ${ }^{1}$

Michael Hutt is Lecturer in Nepali at the School of Oriental and African Studies, University of London.

(C) 1991 by The Regents of the University of California

1. For an in-depth analysis of Nepali politics between 1950 and 1964, see Bhuwan Lal Joshi and Leo E. Rose, Democratic Innovations in Nepal (Berkeley: University of California Press, 1966). See also Hem Narayan Agrawal, Nepal: A Study in Constitutional Change (New Delhi: Oxford University Press, 1980). For English translations of earlier constitutions, see The Constitution of the Kingdom of Nepal (New Delhi: Nepal Book Centre, 1959), and The Constitution of Nepal with First, Second, and Third Amendments (Kathmandu: 


\section{MICHAEL HUTT 1021}

The following chronology of the struggles, debates, and controversies surrounding the framing of the 1990 Constitution from the legalization of political parties in April to its promulgation in November demonstrates the extent to which uncertainty persists in Nepal about the direction in which political development should proceed, the role the monarch should play in this development, and the uncertainty of the palace itself about the extent of its own power in the future. There is also evidence of a significant disparity between popular priorities for change and those of the national leadership.

On the morning of April 6, 1990, King Birendra broadcast a proclamation on Radio Nepal to the nation that was remarkable for the concessions it made to the Democracy Movement, especially in view of the administration's former intransigence. Charging the Council of Ministers with failure to understand the "tradition of public consent" and causing loss of life and property, the king announced the formation of a new council (under National Panchayat member Lokendra Bahadur Chand) that would hold talks with "people holding different political views." The king invoked Article 81(1), "Formation of the Council of Ministers in Extraordinary Circumstances," of the 1962 Constitution, and he also promised to form two committees, one for constitution reform suggestions and one to investigate recent violence.

The Democratic Movement was launched by an alliance between the Nepali Congress Party and the newly formed United Left Front (Sanyukta Bam Morcha, ULF) on February 18 and had reached its climax by early April, resulting in massive civil disorder throughout the kingdom. ${ }^{2}$ When security forces shot several dozen unarmed demonstrators in the streets outside the royal palace on April 6, despite the king's concessions that very morning, the situation had clearly deteriorated to such an extent that even the movement's leaders were only nominally in control. Factions within the movement were escalating their demands, calling not for a constitutional monarchy but for the abolition of the monarchy itself. ${ }^{3}$ To restore

HMG, Ministry of Law and Justice, 4th ed., 1983). Agrawal summarizes the Rana Constitution of 1948 (pp. 8-21) and the Interim Constitution of 1951 (pp. 22-31).

2. The Nepali Congress, the oldest and most broadly based party in Nepal, was formed during the last years of the Rana regime. It is of a general center-left political complexion and represents a diversity of interests. The ULF was a coalition formed in late 1989 by eight factions of the Nepal Communist Party (NCP).

3. The mood in the Kathmandu Valley after the royal proclamation of April 6 was joyous. It is not at all clear why this mood changed so dramatically during a mass meeting on the Tundikhel parade ground that afternoon, or why a large section of the crowd that had gathered there decided to march on the king's palace. Martin Hoftun, a Norwegian historian who was present in Kathmandu at the time, suggested that this may have been a response to police 
public order, a 22-hour curfew was declared in Kathmandu and Lalitpur from April 7 and in Bhaktapur from April 8.

\section{Legalization}

The king made a further, fundamental concession two days later by lifting the 30-year ban on political parties and deleting the term "partyless" from the 1962 Constitution. After an audience with the king, the four main leaders of the Democracy Movement (Krishna Prasad Bhattarai and Girija Prasad Koirala of the Nepali Congress and Sahana Pradhan and Radha Krishna Mainali of the ULF) announced that the movement had been called off since their two main demands had been granted. During the struggle that followed in subsequent months between the palace and the political parties, the movement leaders were regularly criticized for making this decision too soon. Many activists argued that their demands should have included the abrogation of the 1962 Constitution, the promulgation of an interim act, and the election of a constituent assembly to draft the new constitution. These complaints came from elements within the ULF as well as from parties not represented in it and were leveled principally at the leaders of the Nepali Congress whose response was that, since these demands were not made before April 8, it was not appropriate to make them now.

On April 12 a joint meeting of the Nepali Congress and the ULF made demands that included the dissolution of the National Panchayat and Council of Ministers, the repeal of all provisions of the 1962 Constitution that conflicted with a multiparty system, the dissolution of Panchayat units from village to district level, and the formation of a constitution commission with "adequate representation" of the Nepali Congress and the ULF. In a New Year message to the nation on April 14, the king affirmed: "Politics in Nepal has now taken a new turn. We have upheld the tradition of respecting the popular will and fulfilling the people's aspirations. The Constitution Reforms Commission in the process of being set up in the near future will consult elements of society professing different political views in the course of preparing its report." 4 The palace view at this early stage was clearly that it was at liberty to form a body that would submit suggestions to the king for reforms of the 1962 Constitution. It soon became clear that this view did not accord with that of the Democracy Movement.

provocation or to a call from the Mashal faction (which was not part of the ULF) of the NCP, which had organized the rally.

4. Nepal Press Digest 34:16, April 16, 1990. 


\section{Formation of an Interim Government}

Events moved rapidly after the Hindu New Year had been ushered in. On April 15 five government ministers and five representatives of the Nepali Congress and the ULF sat down in the Royal Nepal Academy to begin negotiations. Outside, several thousand demonstrators surrounded the building, demanding the dissolution of all Panchayat institutions and the formation of an interim government. The participants in this meeting were effectively besieged: when the newly appointed Prime Minister Chand attempted to leave, his car was wrecked by the crowd. Clearly the more radical elements feared betrayal.

Nevertheless, the negotiators escaped from the academy after 14 hours of talks, and the next day a royal proclamation announced the resignation of the hapless Chand ministry after only ten days in office, as well as the dissolution of the National Panchayat, the Panchayat Policy and Evaluation Committee, and the Class Organizations. ${ }^{5}$ Clause (2) of Article 81 of the 1962 Constitution, which empowered the king in extraordinary circumstances to suspend articles 25 to 29 on the formation and functioning of the Council of Ministers and dissolution of the National Panchayat, was invoked to do just that. Articles $41 \mathrm{~B}$ and $67 \mathrm{~A}$ that provided for the Panchayat Policy and Evaluation Committee and the Class Organizations, respectively, were suspended, as was clause $2 \mathrm{~A}$ of Article 11, which prescribed that "no political party or any other organisation, union, or association motivated by party politics shall be formed or be caused to be formed or run." Later the same day (April 16) the king asked Ganesh Man Singh, the supreme leader of the Nepali Congress, to form an interim government but Singh declined on grounds of ill-health and asked the king to head the government himself. This the king declined to do, and eventually Krishna Prasad Bhattarai, the party chairman, was selected, with the ULF's agreement. Portfolios were allocated on April 18 and the new prime minister was sworn in the following day. The new Council of Ministers was made up of 11 ministers-four members of the Congress, three of the ULF, two independents with records of work in human rights organizations, and two palace nominees. ${ }^{6}$

5. Article $67 \mathrm{~A}$ of the 1962 Constitution provided for the formation of six class organizations of women, peasants, youths, elders, laborers, and ex-servicemen "with a view to integrate and utilize the united strength of the various classes." Membership in one of these class organizations was made "compulsory for any person contesting as a candidate in the election of any level of Panchayat." (The Constitution of Nepal [Kathmandu HMG, 1983]).

6. The new ministers (mantri-parishad) were: Krishna Prasad Bhattarai, Mahendra Narayan Nidhi, Yoga Prasad Upadhyaya, and Marshal Julum Shakaya (Congress); Sahana Pradhan (NCP [Marxist]), Nilambar Acharya (NCP [Manandhar]), Jhal Nath Khanal (NCP 
On the left of the political spectrum, few groups were willing to trust the palace to make its promised concessions to democracy. The editorial of the Drishti newspaper on April 18 declared, "the King cannot be a leader. No one can be above the Constitution. The King must stay in his palace ... if the Crown tries to support dictatorial ideals, a movement will be launched which will abolish the monarchy itself."7 The ULF parties had probably reconciled themselves to the retention of a constitutional monarchy in order to achieve a working compromise with the Nepali Congress, but leftist groups outside the front, such as Mashal, considered this a temporary measure-a step on the way to a totally republican state. ${ }^{8}$ Thus, they orchestrated a hue and cry each time the king appeared to take decisions without what they considered sufficient consultation.

From this time onward, various groups began to make their own demands regarding the new constitution. The Movement for the Restoration of Democracy had not been a constitutional movement as such; its demands were not couched in constitutional intricacies but were simply for the legalization of parties, a constitutional monarchy, and a respect for human rights. Once the movement was called off, a large number of new parties emerged, many of which represented ethnic, religious, and regional concerns. On April 23 the situation in the Kathmandu valley approached anarchy when six policemen were beaten to death and subsequent police firing killed about a dozen demonstrators. By April 26 night curfews had been imposed throughout the valley. The widespread rumor of an imminent palace-led coup was eventually squashed on April 25 when the palace issued a press release in which the king urged the nation to support the interim government: "The interests of the country and the people lie in the development and strengthening of multi-party democracy. The Government headed by Krishna Prasad Bhattarai should be fully supported." On April 24 the Nepali Congress and the ULF issued a joint directive to the interim government that made the following points about the new constitution:

The new Constitution must be fully democratic; the King must become a constitutional monarch; the King must act only on the advice of the Council of Ministers. All institutions and laws not conducive to democraticisation must be repealed. Democratic rights must be ensured for all citizens. Institutions and

[Marxist-Leninist]); Devendra Raj Pandey and Mathura Prasad Shreshtha (independents); and Keshar Jang Rayamajhi and Achyut Raj Regmi (royal nominees).

7. Nepal Press Digest 34:17, April 23, 1990.

8. Led by "Prachand," the Mashal faction of the NCP remains committed to Maoist revolution and denounces the Marxist-Leninists for their revisionism. It is not to be confused with the Masal faction, led by Mohan Bikram Singh, from which it split in 1981.

9. Nepal Press Digest 34:18, April 30, 1990. 
processes must be developed for the protection of democracy. A free election must be held as soon as possible, and an independent Election Commission must be formed for this purpose. There should be press and academic freedom, and equal rights for women. ${ }^{10}$

\section{The Constitution Commission}

The questions of who should frame and approve the new constitution were debated fiercely for weeks, and the eventual solution to the problem did not find favor in all quarters. Most of the leftist parties outside the ULF demanded the promulgation of an interim constitution and direct elections on a political party basis to a constituent assembly. Several groups- notably the Nepal Communist Party (4th Convention), the United Nepal People's Movement, and the Masal and Mashal factions-continued to make these demands throughout the year, and when the new Constitution was finally promulgated, they refused to recognize it. The leaders of the Nepali Congress resisted very vigorously. On May 4 Mathbar Singh Basnet, one of the four official spokesmen for the party, dismissed the idea of a constituent assembly as an "intellectual luxury" on the grounds that all parties, including the Congress and the communists, had contested the 1959 general election under a constitution promulgated by King Mahendra. ${ }^{11}$ It may be that the Congress felt, as supreme leader Singh later stated, that the king could not be pushed too far too fast and that the notion of a constitution, which derived from the people and not the king, would provoke a reaction from the palace. It is also clear that the policy of "national reconciliation" between the palace and the people pursued by the late B. P. Koirala continues to be a part of Nepali Congress philosophy. ${ }^{12}$ On July 6 Singh quoted B. P. Koirala as having said, "in a tussle between the Nepali Congress and the King, democracy would be the only casualty." 13 The official line pursued by many Congress spokesmen, however, was that an interim act and the election of a constituent assembly would delay the general election, and that this was the communists' real objective in making such demands.

Soon, however, it seemed that the Congress's trust in the palace to conform with democratic norms had been misplaced, or else that the two sides had not fully understood one another's aims. On May 11, without consult-

10. Ibid.

11. Nepal Press Digest 34:19, May 7, 1990.

12. See Shashi P. Mishra, B. P. Koirala: A Case Study in Third World Democratic Leadership (Bhubaneshwar and Varanasi: Konark, 1985); also B. P. Koirala, Melmilapko Sharta: Räshtriyatā ra Prajātantra (Arguments for harmony: INationhood and democracy) (Kathmandu, 1982).

13. Nepal Press Digest 34:30, July 23, 1990. 
ing the interim government, King Birendra formed a seven-man Constitution Reforms Recommendation Commission and directed it to submit recommendations to him within three months for changes to the 1962 Constitution. This was in direct contradiction to the ULF's demand for a commission that would include representatives of both political parties within the interim government. Prime Minister Bhattarai shamefacedly admitted that he had not been consulted by the king before the formation of the commission. Demonstrating what appeared to be genuine political naiveté, he said that there were no real grounds for discontent, since the king had advised him that the government would be free to reject the new constitution. "The King told me," he said, "he was not aware of the fact that there is a party behind me which has to be satisfied, because there have been no political parties functioning in the country for a long time. $\mathrm{He}$ also did not consider such matters as the fact that there was a coalition Government. So it has happened."14

Predictably, few leaders were as sanguine as Bhattarai about this attempt by the palace to capture the constitution-drafting process. Girija Prasad Koirala, the general secretary of the Congress, described it as "a great insult to the people of Nepal." He rejected the idea of reforming the 1962 Constitution and demanded a completely new dispensation. The commission should be dissolved immediately, he said, and in this he received the support of most leftist leaders. The ULF described the formation of the commission as "undemocratic and disgraceful" and the Congress called for its dissolution and reconstitution in consultation with the interim government. This incident was the first of several palace attempts to regain, as it were, the high ground during the drafting of the new constitution. On each occasion, a hostile reaction from the press, the public, and political parties forced a retreat, but such incidents demonstrated either that the king and his palace secretariat were not sincerely committed to the direction of political change upon which Nepal had embarked (the leftist view, perhaps) or that the king, inexperienced in dealings with free and active political parties, was adjusting only slowly to the changed circumstances (the public view of some in the Congress).

In any event, the palace ploy was a damp squib. The commission's chairman, Justice Bishwanath Upadhyaya, resigned and three of the six other members refused to join at all. The commission was dissolved after only four days. Unprecedented criticisms were leveled at the king. Man Mohan Adhikari of the NCP (Marxist) had already said, "the King should no longer be considered an incarnation of Vishnu. He too is a man, and a man can make mistakes." The Drishti weekly of May 16 exclaimed, "the

14. Nepal Press Digest 34:20, May 14, 1990. 
nation has been stunned by what His Majesty did on May 11. That step . . . was clearly aimed at turning the monarchy once again toward the tendencies of the Panchayat period, and reinstating the despotism of the Palace in every vital sphere." 15 This incident revived the demand for an interim constitution that vested sovereignty in the Nepali people, a demand that was taken up even by some senior Congress officials. Bhattarai was instructed to consult the Council of Ministers and other parties in nominating members for a new commission. Adhikari, filled with righteous indignation, demanded that the new body should not include anyone who had connections with the palace, the administration, or the "black history" of the previous 30 years. ${ }^{16}$

On May 22 the king vested the legislative and executive powers of the dissolved National Panchayat in the interim government, under Article 81(2)(b) of the 1962 Constitution. Despite this, Singh complained on June 1 that the government was still hindered by a lack of judicial power, which had not yet been granted to it. Critics of the government said that it was still operating under the 1962 Constitution, minus the word "partyless," and that it therefore still sought palace approval for every move it made. Policy guidelines, issued for the interim government on June 4, stated: "The main tasks of the Interim Government will be to maintain law and order, develop a multi-party system on the basis of Constitutional monarchy, draft a new Constitution, and hold General Elections." 17

A new Constitution Recommendations Commission nominated by Bhattarai was inaugurated by the king at the end of May. The nine-member commission was again chaired by Justice Upadhyaya of the Supreme Court. The main political parties accorded the commission a cautious welcome. Adhikari objected to the inclusion of the word "recommendations" in its title, while leaders of the Marxist-Leninist faction of the NCP demanded that it should form a new constitution, which should be presented to the interim government for final approval, not to the king. Soon after the formation of the commission, Justice Upadhyaya explained that each of its members had been assigned specific topics on which they would collect suggestions from political parties and the general public and report back to the commission. A deadline of July 4 was set for the submission of suggestions. Later in the month, six members of the commission were sent out to tour various zones of the country to canvas opinions, and the Congress lawyer, Daman Dhungana, was sent to Britain to study constitu-

15. Ibid.

16. Ibid.

17. Nepal Press Digest 34:24, June 11, 1990. 
tional issues, especially relations between an elected government and the crown.

Justice Upadhyaya later expressed dismay over the fact that the vast majority of suggestions submitted to the commission concerned linguistic, religious, ethnic, and regional issues. Since the "unification" of Nepal in the late eighteenth century, political power had been monopolized by the "twice-born" Brahmin and Chetri castes, and the language and culture promoted by the government have been those of the Hindu populations of the hill regions. ${ }^{18}$ The "tribal" hill people who speak Tibeto-Burman languages, such as the Rai, Limbu, Tamang, and Gurung, are underrepresented at all levels of government, while the Tarai population-many of whom are of more recent Indian origin-suffer discrimination at the hands of the state bureaucracy. The demands made to the Constitution Recommendations Commission for recognition of languages other than Nepali and religions other than Hinduism and for the proportional representation of minority groups in the legislature reflect the growth of communal grievances among minority and regional groupings in Nepal that are based on socioeconomic realities. Rather than attempting to accommodate these grievances, the commission and the interim government simply perceived them as a threat to national unity, and virtually dismissed them out of hand. Thus, Justice Upadhyaya said it was "unfortunate" that most suggestions had been about "peripheral" issues, and he called upon all political parties to educate the people on basic constitutional subjects. ${ }^{19}$

In an interview on July 9, Upadhyaya confirmed that most political parties had made identical suggestions for a constitutional monarchy, a multiparty democracy, adult franchise, a bicameral legislature, and the sovereignty of the people. But he expressed some concern over the procedure to be adopted for the promulgation of the new constitution: "The individual or institution who gives the Constitution is sovereign. The people will be sovereign if there is a Constituent Assembly, but we have not followed that path. If the Constitution is granted by the King, under what power should he do so?" 20 The NCP (Masal) concurred with this view: "We do not believe that the King will give up his powers and hand over sovereignty to the people. After all, even the new Constitution will be a gift from the King. How can a mango tree bear oranges?"21

18. Martin Hoftun remarked in a lecture at the School of Oriental and African Studies on January 24, 1991: "The Brahmin and Chetri leaders of the Congress and Communist parties wanted democracy, but by their mere leadership they upheld the political domination of an elite."

19. Nepal Press Digest 34:27, July 2, 1990.

20. Nepal Press Digest 34:29, July 16, 1990.

21. Nepal Press Digest 34:30, July 23, 1990. 


\section{Suggestions Made to the Constitution Recommendations Commission}

Most political parties agreed on the basic features of the new constitution. Other than these, the main points of controversy were religious freedom; the status of Nepali and the other languages of Nepal; the rights and representation in the administration of ethnic minorities, depressed castes and classes, the Tarai peoples, and women; and control of the army.

Religious freedom. Two articles of the 1962 Constitution that concerned religion aroused controversy. Article 3(1) stated, "Nepal is an independent, indivisible, and sovereign monarchical Hindu kingdom," while Article 14 on "Right to Religion" (identical to Article 5 in the 1959 Constitution) stated, "every person may profess his own religion as handed down from ancient times and may practice it having regard to tradition. Provided that no person shall be entitled to convert another person from one religion to another." Under this article, a number of people had received prison sentences for allegedly converting Nepali citizens to Christianity. The debate on these issues quickly became an impassioned argument between secular state and Hindu state proponents. Those demanding a secular state included Buddhist, Muslim, and Christian associations; ethnic organizations representing the predominantly non-Hindu, Tibeto-Burman tribes; and leftist, liberal, and republican elements. An enormous demonstration organized by the Nepal Buddhist Association to demand a secular state brought some 10,000 marchers onto the streets of the capital on June 30.

These demands were strongly opposed by traditionalist Hindu organizations, particularly the Sanatan Dharma Seva Samiti and the Nepal committee of the Vishwa Hindu Parishad. The interim government's Minister for Housing, Achyut Raj Regmi, caused an uproar when he threatened a hunger strike if the constitution made Nepal a secular state. And when 12 "religious prisoners" had their sentences remitted on June 15, the weekly Bimarsha claimed that the state had already become secular, even before the constitution had been drafted. ${ }^{22}$ The traditionalist Hindu stand reflected concern that the declaration of Nepal as a secular state would open its borders to a flood of Christian missionaries, who might have political as well as religious patronage and motives. This paranoia became evident during June, when several proestablishment newspapers carried reports of mass conversions to Christianity in outlying districts. ${ }^{23}$

22. Nepal Press Digest 34:26, June 25, 1990.

23. The Vishwa Hindu Parishad sent a. 108-member delegation to Upadhyaya on June 6, claiming that 30,000 Nepalis had been converted to Christianity since April. (Nepal Press Digest 34:24, June 11, 1990.) The Jana Jagriti newspaper of July 2 reported that 48,000 had 
The language issue. The demands of communal groups ranged from suggestions that Nepali should continue to be the national language but that other languages should be given some kind of constitutional status to demands that Nepali's status as a national language be abolished and that Nepal should become a federal state with each autonomous region having its own official language. There were strident calls from groups such as the Tarai-based Nepal Goodwill Council for the recognition of Hindi as a second national language. ${ }^{24}$

Human rights. HURON (Human Rights Organization of Nepal), FOPHUR (Forum for the Protection of Human Rights), and Amnesty International all called for the abolition of the death penalty and for the endorsement by the government of international human rights conventions. ${ }^{25}$

Control of the army. On June 23 a controversial circular was sent to all units of the Royal Nepalese Army directing them to submit the following suggestions to the Constitution Recommendations Commission: the king must continue to be the supreme commander-in-chief and field marshal of the army; the king should appoint the commander-in-chief, who should have constitutional status; and sovereignty should be vested in the king. Nepal should also remain a Hindu state. ${ }^{26}$

On June 27 Nirmal Lama, leader of the NCP (4th Convention), threatened to resign from the Constitution Recommendations Commission and expressed strong doubts that the king would approve the new constitution without extensive amendments. Clearly, the suspicion was growing that events were moving in the same direction as they had under King Mahendra in 1959-60; in that instance, the demand for a constituent assembly had also failed, the king had promulgated the constitution at the very last minute, only a week before the general election, and had revoked it and banned parties within 18 months. These suspicions were subsequently fueled by the king's appointment of ambassadors without consultation with the interim government. On August 8 posters appeared in

been converted in one day in Dhading District "due to financial allurements." (Nepal Press Digest 34:28, July 9, 1990.)

24. These demands were not new; they were advanced vigorously during the 1950 s and early 1960s, before King Mahendra's "royal coup" stifled debate. See Frederick F. Gaige, Regionalism and National Unity in Nepal (Berkeley: University of California Press, 1975). On the other hand, the demands made by speakers of Tibeto-Burman languages other than Newari were quite without precedent.

25. An Amnesty International mission visited Nepal in April 1990, and a memorandum was sent to the interim government in June recommending the incorporation of human rights safeguards in the new constitution.

26. Nepal Press Digest 34:29, July 16, 1990. 
Kathmandu in the name of Lama's party, claiming that a palace conspiracy was underway. The posters claimed that the Constitution Recommendations Committee was being manipulated by the palace and forced to adopt provisions such as prohibiting debate of the king's conduct in the legislature. The posters were quickly removed and arrests were made, but even in January 1991, there were still slogans painted by the NCP (4th Convention) on Kathmandu streets. Mysteriously, however, Lama did not resign. By late August, he was promising that the new constitution would be even more democratic than the one promulgated in 1959. For instance, the king would not possess the power to declare an emergency as he had under Article 55 of the 1959 dispensation. Lama's change of stance may have been prompted by the compromise achieved between the ULF and Congress representatives on the commission, which led to accusations of the commission exceeding its brief. On August 23 Justice Upadhyaya announced that the draft of the new constitution would be submitted to the king on August 31 and that the king would hand it over to the Council of Ministers for their perusal on the same day. He admitted that the members of the commission had not yet reached a decision on the issues of whether Nepal should be a Hindu or a secular state and of how the army should be controlled.

From the end of August until the actual promulgation of the constitution on November 9, the story is one of delay and controversy and of several apparent attempts by the palace to water down the document and retain the maximum possible powers. On August 31 Justice Upadhyaya announced the completion of the draft, an outline of which appeared in the Gorkhapatra the following day. The constitution contained provisions for amending its three basic features of constitutional monarchy, multiparty democracy, and the vesting of sovereignty in the people. Some newspapers interpreted this as evidence of republican forces having undue influence in the commission-not a very convincing argument since under the draft constitution any change in the status of the monarchy could only be made with the monarch's prior consent. Other papers suggested that this was the work of "reactionaries," and commentators from all angles returned to the old theme of the palace stirring up controversy to delay promulgation and undermine democracy.

The most likely explanation advanced for the surprising inclusion of these provisions appeared in the Gorkhapatra on September 1. The Nepali Congress had held the view for many years that the new constitution should enshrine the three basic features mentioned above. According to the Gorkhapatra, the ULF representatives on the commission announced at the eleventh hour that they had no faith in the first two of these. After a furious debate, the chairman achieved a compromise by including provi- 
sions for amendment of these three concepts on the basis of a threequarters majority vote in the legislature and a national referendum. $\mathrm{He}$ said, "the Constitution cannot be said to be binding on future generations. It can be amended, but a complex process has been adopted for amendments, in the belief that certain provisions should not be amended as easily as others." 27 From this time onward, the leftist parties, who believed that they had scored a victory with the inclusion of these provisions, demanded immediate promulgation without changes, while the Congress continued to look for an opportunity to make these concepts inviolable. The palace, meanwhile, found a chance to exploit these differences to its own advantage.

Justice Upadhyaya presented that draft of the new constitution to the king on September 10. The king then handed it to Bhattarai as agreed but sparked further controversy by instructing him to consider suggestions put forward by constitutional organs and political parties that had not been represented in the Recommendations Commission. On the advice of the Council of Ministers, he then extended the term of the commission up to the day of promulgation. There were widespread objections to the king's directive, most of which emanated from the Left, which demanded immediate promulgation. It was protested that "anti-people" elements would now have a say and that promulgation would be endlessly delayed. The Congress, however, did not complain too loudly; its opposition to the provisions for amendment were widely known, and there were probably also objections to the king's right to appoint ambassadors and to an article that required a two-thirds majority in both houses for the ratification of treaties with foreign countries. On September 26, G. P. Koirala said that it had been a "suicidal" decision to put the basic features of the constitution into a "state of uncertainty," since it would compel the king to engage actively in politics in order to safeguard his position. ${ }^{28}$

The Council of Ministers reportedly made over 20 changes to the draft. $^{29}$ The most important of these made it impossible to repeal or amend provisions if such an amendment contravened the spirit of the preamble, and another made it possible for Parliament to ratify treaties by a simple majority, except those treaties that related to strategic or military alliances or to the boundaries of Nepal. Apparently ULF representatives acquiesced to these changes after veiled threats had been made by the Congress to withdraw all cooperation if they did not. The constitution was submitted to the king by the prime minister on October 11, and the king

27. Nepal Press Digest 34:38, September 17, 1990.

28. Nepal Press Digest 34:40, October 1, 1990.

29. Nepal Press Digest 34:42, October 15, 1990. 
announced that he would study it, "to determine to what extent it was positive in the exercise of democracy." 30

\section{The Palace Draft: A Final Crisis}

On October 16 the palace announced that the constitution would not be promulgated until after the national holiday of Tihar (i.e., after October 20) and that consultations were still going on between the king and the prime minister. Some press reports suggested that the king had asked for improvements in the "language and organization" of the document; others felt that he had raised strong objections to a reference to the Democracy Movement in its preamble. On October 21 it became apparent that the palace had had objections to many other features of the constitution when a new draft was released to the press. It was claimed that this had been prepared jointly by the king and the prime minister, but it contained many fundamental differences from the revised draft submitted by the Council of Ministers. Some of the changes made in its preamble are summarized below:

\section{Original draft}

"in accordance with the desire expressed by the people of Nepal through the historic people's movement for Constitutional change"

"Framed through the broad participation of the Nepali people in accordance with their desires"

\section{Palace draft}

clause removed

$$
\begin{aligned}
& \text { "Whereas the happiness and } \\
& \text { prosperity of Nepal and the Nepali } \\
& \text { people have always been our sole } \\
& \text { objective, and we are determined to } \\
& \text { achieve that objective, and whereas it } \\
& \text { is desirable to frame and promulgate } \\
& \text { a Constitution..." }
\end{aligned}
$$

"We hereby proclaim and promulgate this Constitution . . .

"on the advice and with the approval of [the] Council of Ministers"

"Whereas we have expressed the determination from time to time to run the polity in accordance with the popular will"

(Sovereignty vested in the Nepali people)
". . . in accordance with the

Constitutional laws, customs, usages and traditions of Nepal."

"Whereas our revered forefathers and ourselves have been running a polity based on the public will"

"The sovereignty of Nepal shall be vested in the Nepali people, including His Majesty"

30. Ibid. 
According to the palace draft, there was to be a Rāj Parishad (council of state) to be appointed by the king with duties prescribed by the constitution. A standing committee would offer advice to the king when requested and submit an annual report to him. Emergency powers were assigned solely to the king, who would have to present his proclamation of a state emergency post facto before the legislature within three months. The executive, legislative, and judicial powers of the kingdom were all vested in the king, and would be exercised "in accordance with the Constitution and current law." 31

The interim government was stunned. Ganesh Man Singh said, "it is quite undemocratic to seek to promulgate a Constitution similar to that of 1962. No sane person can do it." Bhattarai told the king's principal secretary to convey his resignation to the king, since he would be unable to gain endorsement of the draft from the Congress Party, the government, or the people. Leftist parties, student unions, and professional associations took to the streets to denounce the "palace conspiracy." The palace feigned surprise at the ferocity of this response. Disingenuously, a press note expressed surprise at Bhattarai's offer of resignation, claiming that he had been fully consulted - something the prime minister denied. After hasty discussions between the king and Bhattarai, the palace backed down: a press note issued on October 23 said the royal draft was a "proposed draft" only. Two days later promulgation was promised for November 9.

One of the most striking features of this story is the extent to which its final stage turned into a fundamental struggle over the constitution between the palace and the interim government. It was a simple matter, devoid of democratic or constitutional niceties, of putting pressure on the king to remake the concessions that had officially been made several months before. Outside the palace gates, there was a general strike in Patan and a mass ULF rally in Kathmandu on October 27, while leftists burned copies of the palace draft and threatened to launch a new republican movement if the original constitution was not promulgated on November 9 . Inside the palace, the king spent four-and-a-half hours in talks with Congress leaders and Justice Upadhyaya on October 24. By the end of the day, agreement had been reached on the issues of multiparty democracy, constitutional monarchy, the vesting of sovereignty in the people, and human rights. The national anthem and the privileges of the royal family were still under discussion. G. P. Koirala warned, "we must remain alert, since we cannot be sure of anything until the Constitution is promulgated." 32

31. Nepal Press Digest 34:44, October 29, 1990.

32. Nepal Press Digest 34:45, November 5, 1990. 
On November 9 it became clear that a compromise had been achieved that generally favored the demands of the Democracy Movement but still reserved important powers and privileges for the monarchy. Bhattarai described the 1990 Constitution as "a historic document" that guaranteed there would never again be "one-man rule" in Nepal. The moderate leftist groups accorded it a qualified welcome, but the NCP (4th Convention) and the ethnic and communal parties rejected it out of hand, since their demands had not been fulfilled. Proclaiming the constitution, King Birendra referred to the fact that democracy had been established in Nepal in 1951 "through the cooperation of the King and the people," and ended with the long-fought-over sentence, "we hereby promulgate and enforce with immediate effect on the recommendation of the Council of Ministers the draft prepared by the Commission as the Constitution of the Kingdom of Nepal, 1990" (emphasis added).

\section{The Main Features of the New Constitution}

An "unofficial" English translation of the 1990 Constitution is available, although unpublished, but only the original Nepali text has full legal force. ${ }^{33}$ The quotations given below are my own translations.

The Kingdom of Nepal-sovereignty, religion, and language. Article 3 states that "the sovereignty of Nepal is vested in the Nepali people," and is thus uncontroversial. However, Article 4(1) states: "Nepal is a multi-ethnic, multi-lingual, democratic, independent, indivisible, sovereign, Hindu, Constitutional monarchical kingdom." The terms "multi-ethnic" and "multi-lingual" were probably intended to mollify the minorities who had been pressing claims on behalf of their languages and regions for months. But many commentators have objected to the insertion of the word "Hindu" here. They argue that, since the position of the Hindu king is safeguarded by Article 27(1) - which states that the king must be a descendant of Prithvinarayan Shah, an upholder of the Aryan culture, and a practicing Hindu-there was no need for Article 4(1) to make any statement whatsoever on either religion or secularism.

33. The Nepali text of the 1990 Constitution was reproduced in the Gorkhapatra of 24 Kartik 2047 (10 November 1990) and later in booklet form by the publishers of the magazine Antarrashtriya Manch (International Forum). Vol. 48 of the latter journal carries summaries on pp. 309-11 and pp. 350-54. See also "Samvidhān: Krānti kì Agni Parikshā se Milā Pramān Patra" (The constitution: A certificate received from the fire-test of revolution) in the newly launched Hindi journal, Nava Nepal, vol. 1, pp. 6-12, and the "Constitution Special Edition" (Samvidhän Vishesh) of the monthly Sindhu 21:5 (December 1990-January 1991). 
The 1990 Constitution also adopts a somewhat ambiguous position on the question of language. Whereas Article 4 of the 1962 Constitution simply stated, "the National Language of Nepal is the Nepali language in the Devanagari script," the 1990 document hedges its bets by dividing its Article 6 into two clauses: 6(1) "The Nepali language in the Devanagari script is the state language (rāshțrabhāshā) of Nepal. The Nepali language shall be the language of the workings of Government." 6(2) "All languages spoken as mother-tongues in the various parts of Nepal are national languages (rāshṭrīya bhāshā) of Nepal.” Article 18(2) goes rather further, stating: "Every community shall be able to run schools so that education may be provided to children up to the primary level in their mother-tongues."

The above articles were probably drafted to appease linguistic and religious minorities. But it is already apparent that groups such as the Nepal Goodwill Party, which had demanded the status of a second national language for Hindi, along with Christian, Buddhist, and Muslim groups, which had demanded a secular state, are far from satisfied. The dissatisfaction of the Christian minority has been compounded by the fact that Article 14 of the 1962 Constitution that banned conversion has been retained as Article 19. This is certain to lead to continued protests by Christian and human rights organizations since, if interpreted narrowly, it seems to require one to follow the religion of one's ancestors, not that of one's own choosing, and thus it has been claimed it contravenes Article 18 of the Universal Declaration on Human Rights. ${ }^{34}$

The Council of State (Raj Parishad). The council is to be formed by the king as an advisory body and is to designate a regent in the case of his mental or physical infirmity. This Raj Parishad, which consists of members of the royal family, the cabinet, and leading national figures, is modeled on the Raj Sabha of the old constitution but holds fewer powers.

The executive. Executive authority in Nepal is vested in the king and the Council of Ministers, and the constitution makes it clear that all functions discharged by the king (other than those explicitly stated by the constitution to be discretionary) should be discharged on the advice and with the consent of the Council of Ministers. The king is to appoint as prime minister the leader of the party or coalition of parties that wins a clear majority in the House of Representatives. These provisions contrast strongly with those of 1962; Article 20(2) of the old constitution began: "The sovereignty of Nepal is vested in His Majesty and all powers-executive, legislative, and judicial - emanate from Him," while Article 24(2) stated: "The

34. Rishikesh Shaha, "A Good Constitution that Could Be Better," Himal 3:4 (November-December 1990), pp. 28-29. 
question of whether His Majesty has consulted any person or authority under the provisions of this Constitution ... shall not be inquired into by any court."

The legislature. The legislature is to consist of three elements: the king, a House of Representatives (Pratinidhi Sabhā) consisting of 205 members each elected from a district constituency; and a National Assembly (Rāstriya Sabhä) consisting of 60 members of whom 10 will be royal nominees-reputed persons who have made distinguished contributions to national life-35 (including at least three women) will be elected by the House of Representatives, and 15 will be elected from the five development regions through an electoral college system. The term of the House of Representatives will be five years, while the National Assembly will be a permanent body, with one-third of its members retiring every two years.

The form of the legislature represents a return to the 1959 Constitution, which provided for a 36-member Senate and an elected House of Representatives. In 1959, however, the king nominated 18 of the 36 senators, who served six-year terms, while the House of Representatives had only 109 seats. The king, therefore, has far less say in the membership of his government now than he did under the democratic Constitution of 1959.

The judiciary. The constitution provides for a three-tier judiciary-a Supreme Court, Appellate Courts, and District Courts. The chief justice is to be appointed on the recommendation of a constitutional council, other justices of the Supreme Court on the recommendation of a judicial council. The Supreme Court will have the power to declare any law ultra-vires of the constitution.

Political parties. There appears to be almost total freedom to form political parties. However, a party must conform to certain rules if it is to be permitted to stand in national elections. It must not restrict membership on the basis of religion, community, caste, or region; its constitution and regulations must be democratic; its executive officebearers must be elected at least once every five years; and at least $5 \%$ of its candidates in elections must be women. ${ }^{35}$

Emergency powers. Article 81 of the 1962 Constitution entitled the king to revoke the constitution in its entirety and assume to himself all powers of government-which is exactly what King Mahendra did in 1960 under a similar provision (Article 55) of the 1959 Constitution. There was, as a consequence, great concern lest the 1990 Constitution should again grant

35. Under these rules, 3 of the 47 parties that applied to the Election Commission for registration early in 1991 had their requests turned down. 
emergency powers to the king. This it most certainly has not done, but commentators such as Rishikesh Shaha point out a number of contradictions and ambiguities. According to Article 115, the king can declare a state of emergency in the event of a "grave threat to the sovereignty, unity, or security of any part of Nepal due to war, outside attack, armed rebellion, or serious economic disruption." The king's proclamation must be ratified by the House of Representatives within three months. Shaha claims that the constitution is not clear enough on the important question of whether the king is at liberty to proclaim a state of emergency without consulting his government. How, he asks, could the king "be expected to act by and with the advice and consent of the Council of Ministers [as laid down in Article 35(2)] while giving it advice and encouragement [as laid down in Article 43(2)]?" Shaha also claims that a clause that explicitly required the king to seek the consent of the Council of Ministers before declaring an emergency was deleted from the Constitution Commission's draft. But this may have been necessary in the event of an emergency arising when there is no Council of Ministers to give its consent as can happen in a parliamentary system.

Amendments. Bills seeking to repeal or amend provisions of the constitution may be tabled in either house, providing they do not "contravene the spirit of the Preamble." Such amendments require a two-thirds majority and the king's approval, although the king must approve such bills if they are presented to him a second time.

The Royal Nepal Army. A compromise was reached on the matter of control of the army. The king is to retain the title of supreme commanderin-chief but will appoint the commander-in-chief on the prime minister's recommendation, and a National Security Council headed by the prime minister will take charge of all other military operations.

\section{Conclusion: Did the Mango Tree Bear Oranges?}

The new constitution did meet the demands of the Democracy Movement: political parties are free to organize, the proportion of the legislature that is directly elected is larger than it has ever been, and the power of the palace, though still substantial, has been greatly reduced. But communal groups have been granted only minor, nonfundamental concessions. Though Radio Nepal now broadcasts news bulletins in Hindi and Newari, full news summaries may only be heard in Nepali or English. Similarly, Nepali remains the language of government and postprimary education throughout the kingdom. Some concessions have been made to women's groups but these are mostly nominal, while the demand for a secular state 
forced only one change: the granting of a right to all sects and denominations to run and maintain their own institutions. The demands of Tarai organizations have been largely ignored. Human rights groups have been more successful: the death penalty has been abolished, there is protection against discrimination on the basis of religion, race, or gender, and protection against preventative detention. Unfortunately, some of these rights are granted only to Nepali citizens, while the constitution itself discriminates against women in its section on nationality; according to Article 9, the children of male citizens are considered Nepali by descent, while those of female citizens must reside in Nepal for 15 years before they can become citizens.

The 1990 Constitution of Nepal represented something of a compromise between the palace and the Congress, and the Left was slightly marginalized. Republicans cannot be happy with a dispensation that still assigns considerable powers and privileges to the monarch and his family, and it must be admitted that the record of April to November 1990 did give cause for doubt over whether the palace had truly acquiesced to its semiconstitutional role or would actually act in every instance after sincere consultations with elected bodies. This may often have depended on the quality of the advice received by the king himself. On several occasions, King Birendra has acted decisively in line with public opinion, after the people had made their feelings known directly to him. It often seemed in the past, however, that the decision-making process in Nepal was dominated by the highly conservative Palace Secretariat. The weakening of the Secretariat that one assumes has followed the election of a new government can only strengthen democracy in Nepal.

Compared with the earlier constitutions of Nepal- particularly with the 1962 dispensation-the 1990 Constitution represented a dramatic advance in the evolution of a democratic, constitutional order in Nepal. Whether it will actually work in practice depends on whether the palace and the political parties can cooperate in its implementation and whether the growth of communalism witnessed during 1990 will be recognized and contained. Further struggles to amend the constitution are not impossible, although the precedent of 1960-which filled every Nepali politician's mind during 1990 - seems to be fading from view. So far, it seems, the mango tree bears oranges of a sort; the earnest hope in Nepal last year was that the palace would not reach out to pick them again and that the constitution would not be tested by the Supreme Court to establish whether such fruits were forbidden. 